\title{
Kolaborasi Teknik Insight, Modelling, Classical Conditioning sebagai Strategi Konselor dalam Pendidikan Karakter
}

\section{Muhammad Misbahul Huda}

KORESPONDEN PENULIS:

Muhammad Misbahul Huda Universitas Negeri Semarang Jalan Kelud Utara III Petompon, Gajahmungkur, Semarang, Jawa Tengah, Indonesia

Email: Misbah371@yahoo.com

Halaman

$14-21$

\begin{abstract}
This study aimed to describe the implementation of the collaboration of insight, modeling, and classical conditioning technique as the counselor' strategy in the character building. This was a qualitative phenomenological study. This study was conducted in MA Matholi'ul Anwar Karanggeneng Lamongan. This study involved students, school counselors, and the school principal. The data were taken through observations and interviews, while the instrument of the data collection was the observation guideline and interview guideline. To analyze the data, this study employed Miles and Huberman model including the data reduction, the data presentation, and the withdrawal of conclusion. This study found that those techniques possess weaknesses and they could complete each other through collaboration. This study proved that the collaboration of insight, modeling, and classical conditioning technique play a role in students' character building that implies the daily life.

Keywords: Insight, modeling, classical conditioning, character building
\end{abstract}

\begin{abstract}
ABSTRAK
Studi bertujuan untuk mendeskripsikan implementasi kolaborasi teknik insight, modelling, dan classical conditioning sebagai strategi konselor dalam pendidikan karakter. Studi menggunakan pendekatan kualitatif dengan jenis fenomenologi. Studi dilaksanakan di MA Matholi'ul Anwar Karanggeneng Lamongan. Objek studi melibatkan 24 siswa, tiga guru bimbingan dan konseling, dan satu kepala sekolah. Teknik pengumpulan data menggunakan observasi dan wawancara, sedangkan instrumen pengumpulan data menggunakan pedoman observasi dan pedoman wawancara. Analisis data menggunakan model miles and huberman yang meliputi reduksi data, penyajian data, serta penarikan kesimpulan. Hasil studi menunjukkan bahwa dari ketiga teknik mempunyai kekurangan dan dapat saling melengkapi dengan mengkolaborasikan ketiganya. Studi
\end{abstract}

journal.uad.ac.id/index.php/psikopedagogia 
membuktikan bahwa kolaborasi teknik insight, modelling, dan classical conditioning memiliki peranan dalam pendidikan karakter yang berimplikasi dalam kehidupan sehari-hari siswa.

Kata kunci: insight, modelling, classical conditioning, pendidikan karakter

\section{PENDAHULUAN}

Karakter bangsa merupakan faktor penting dalam kemajuan bangsa. Menurut Freud (dalam Prayitno \& Belferik, 2011), kegagalan penanaman kepribadian yang baik di usia dini akan membentuk pribadi yang bermasalah di masa mendatang. Kesuksesan orang tua membimbing anak dalam mengatasi konflik keperibadian di usia dini, sangat menentukan kesuksesan anak dalam kehidupan sosial di masa depan.

Sulitnya penanaman karakter pada siswa selalu menjadi permasalahan para pelaku pendidikan. Permasalahan ini terus berkembang karena objek dari pendidikan adalah manusia yang mengalami proses perkembangan. Terlebih lagi permasalahan penanaman karakter pada usia remaja menjadi kendala terbesar dalam pembentukan kepribadian bangsa sebab masa ini merupakan masa strum und drang (ingin memberontak, gemar mengkritik, suka menentang, mencari jati diri, coba-coba, penasaran, dan sebagainya) (Hidayati \& Purnami, 2008).

Pembentukan karakter yang luhur merupakan tujuan dasar pendidikan. Hal ini termuat dalam UU No 20 tahun 2003 tentang SISDIKNAS yang mejelaskan bahwa pendidikan merupakan usaha sadar dan terencana untuk mewujudkan suasana belajar dan proses pembelajaran agar peserta didik secara aktif mengembangkan potensi dirinya untuk memiliki kekuatan spiritual, keagamaan, pengendalian diri, kepribadian, kecerdasan, akhlaq mulia serta keterampilan yang diperlukan dirinya, masyarakat, bangsa dan negara. Selain tujuan pembentukan karakter yang baik, UU tersebut juga menjelaskan bahwa seorang guru harus memberikan pemahaman dan menciptakan suasana belajar yang mendukung. Guna mewujudkan tujuan tersebut, maka lembaga pendidikan dituntut untuk mempunyai strategi yang efektif dan efesien dalam pencapaian karakter baik pada siswa. Oleh karena itu, pemerintah menggalakan pendidikan berbasis karakter, yang berimplikasi pada penerapan karakter baik dalam kehidupan sehari-hari. Sehubungan dengan hal ini Vess \& Halbur (2003) menjelaskan bahwa jika pendidikan karakter diselenggarakan di sekolah maka konselor sekolah akan menjadi pioner dan sekaligus koordinator program tersebut.

Konselor mempunyai tanggung jawab yang sama dalam tujuan pendidikan sebab konselor merupakan salah satu tenaga pendidik. Hal ini dijelaskan dalam UU SISDIKNAS tahun 2003. Pendidikan karakter merupakan pendidikan budi pekerti plus, yaitu pendidikan yang melibatkan aspek pengetahuan (cognitive), perasaan (feeling), dan tindakan (action). Tanpa ketiga aspek ini, maka pendidikan karakter tidak akan efektif.

Di negara Cina, dalam program reformasi pendidikan yang diinginkan oleh Deng Xiaoping (dalam Kusmanto, 2015), secara eksplisit diungkapkan tentang pentingnya pendidikan karakter:

"Throughout the reform of the education system, it is imperative to bear in mind that reform is for the fundamental purpose of turning every citizen into a man or woman of character and cultivating more constructive members of society."

Oleh karena itu, program pendidikan karakter telah menjadi kegiatan yang menonjol di Cina yang dijalankan sejak jenjang prasekolah sampai dengan perguruan tinggi. Pendidikan karakter tersebut melibatkan aspek pengetahuan (cognitive), perasaan (feeling), dan tindakan (action).

Guna mewujudkan optimalisasi pendidikan karakter yang berimplikasi pada karakter baik siswa dalam kehidupan seharihari, perlu adanya ke tiga aspek, yaitu pemahaman siswa sebagai dasar motivasi terpenting berkarakter baik (insight), realistik model dalam kehidupan sehari-hari sebagai penguat (modelling), serta pengkondisian lingkungan sebagai penguat dan pembiasaan siswa secara menyeluruh (classical conditioning). Oleh karena itu, kolaborasi teknik insight, modelling, dan classical conditioning dinilai efektif sebagai strategi konselor dalam pendidikan karakter.

Studi ini merupakan studi holistik karena meneliti ketiga teknik penting dalam pembentukan tingkah laku manusia yang terpenting yaitu pemahaman pengetahuan yang membentuk pola pikir dan perilaku, contoh dan pengamatan sebagai pembelajaran, serta lingkungan tempat individu hudup. Tujuan studi ini untuk mengetahui kebermanfaatan 
penerapan kolaborasi teknik insight, modelling, dan classical conditioning sebagai strategi konselor dalam pendidikan karakter di MA Matholi'ul Anwar Karanggeneng Lamongan. Studi menghasilkan strategi baru dalam dunia pendidikan untuk mengembangkan pendidikan karakter melalui kolaborasi teknik insight, modelling, dan classical conditioning.

\section{METODE PENELITIAN}

Studi menggunakan metode diskriptif kualitatif dengan pendekatan fenomenologi yang berorientasi pada pengalaman subjektif atau pengalaman yang mengungkap fenomena khusus. Studi dilaksanakan di MA Matholi'ul Anwar Karanggeneng Lamongan. Objek studi melibatkan 24 siswa, tiga guru bimbingan dan konseling, dan satu kepala sekolah. Teknik pengumpulan data menggunakan observasi dan wawancara, sedangkan instrumen pengumpulan data menggunakan pedoman observasi dan pedoman wawancara. Analisis data menggunakan model miles and huberman yang meliputi reduksi data, penyajian data, serta penarikan kesimpulan.

\section{HASIL DAN PEMBAHASAN}

Berdasarkan hasil wawancara dan observasi, diperoleh kesimpulan bahwa teknik kolaborasi insight, modelling, dan classical conditioning yang di lakukan di MA Matholi'ul Anwar Karanggeneng Lamongan efektif membangun karakter siswa, hal ini ditunjukkan dengan terterapkannya 6S (salam, salim, senyum, sapa, sopan, santun), ketertiban berkendara, kegiatan peribadatan, tanggung jawab kebersihan lingkungan sekolah, dan kejujuran siswa dalam ujian.

Siswa yang paham akan pentingnya berkarakter baik akan mudah untuk menerapkan dalam kehidupan seharihari. Melalui contoh dari guru BK ataupun guru-guru lain sebagai model dinilai akan memperkuat pemahaman siswa dan menjadi stimulus bagi siswa sehingga dapat direspon menjadi kebiasaan yang dilakukan. Selain itu pengondisian sekolah dari sarana, prasarana, suasana, dan keadaan siswa juga menjadi faktor penting dalam terterapkannya pendidikan karakter yang diharapkan.

Kolaborasi teknik insight, modelling, dan classical conditioning akan mempermudah sekolah untuk menerapkan pendidikan karakter siswa serta meminimalisasikan karakter buruk siswa. Sebagai upaya implementasi pendidikan dan pembiasaan karakter luhur siswa, konselor MA Matholi'ul Anwar menerapkan kolaborasi ketiga teknik yang mengadaptasi dari teknik-teknik pembelajaran. Penerapan teknik insight learning sebagai upaya pemupukan pemahaman akan karakter luhur. Teknik ini tercermin dalam layanan informasi. Selain rutinitas pemberian informasi dalam bimbingan klasikal kepada siswa, konselor juga memberikan informasi tata tertib kepada wali siswa sehingga langkah ke depannya bisa berproses dengan wali siswa. Melalui pemberian informasi kepada wali siswa diharapkan siswa akan lebih mempersiapkan diri dan dapat menempatkan diri dengan karaker-karakter yang diharapkan oleh sekolah.

Insight yaitu pengamatan atau pemahaman mendadak terhadap hubungan-hubungan antar bagian-bagian di dalam suatu situasi permasalahan. Menurut Uno (2006), insight sebagai gambaran mental sebagai suatu kesatuan persepsi. Abror (2002) secara eksplisit menjelaskan bahwa

"Belajar adalah berkenaan dengan keseluruhan individu dan timbul dari interaksi yang matang dengan lingkungannya. Melalui interaksi ini, kemudian tersusunlah bentuk-bentuk persepsi, imajinasi, dan pandangan baru. Kemudian secara bersama-sama membentuk wawasan atau pemahaman (insight).

Berdasarkan pendapat dua ahli tersebut, maka dapat disimpulkan bahwa insight merupakan gambaran mental individu sebagai hasil interaksi persepsi, imajinasi, dan pandangan baru.

Pemahaman (insight) dalam pemecahan masalah yang mendalam merupakan bagian penting dari pemikiran manusia. Secara tradisional, pemahaman telah diteliti dengan menggunakan seperangkat "tugas tentang pemahaman", dengan asumsi bahwa pemahaman telah terjadi jika suatu masalah dapat dipecahkan (Danek, Wiley \& Öllinger, 2016). Studi yang dilakukan oleh Rogers (1994) menunjukkan bahwa dalam situasi konseling karakter nondirektif, persepsi dan pemahaman baru (insight) tentang diri berkembang secara spontan. Studi menunjukkan bahwa wawasan ini berkembang secara bertahap dalam situasi konseling nondirektif dan meningkat sampai pada puncak kesimpulan dari pengalaman konseling. Studi lain menunjukkan bahwa eksperimen yang dilakukan oleh Kohler 
menunjukkan pentingnya pembentukan insight dalam proses belajar. Pembentukan insight dalam individu terjadi karena ada persepsi terhadap lingkungan atau medan dan menstrukturnya sehingga menjadi suatu susunan yang bermakna, yaitu terbentuknya insight. Kemudian, pemahaman siswa yang menyeluruh akan menciptakan suatu prinsip yang utuh (baik) dalam perkembangan siswa. Berdasarkan hasil studi beberapa ahli yang telah dipaparkan, maka dapat disimpulkan bahwa sangat diperlukan sekali pengembangan insight sebagai pondasi untuk mewujudkan karakter baik dalam diri siswa.

Penerapan teknik modelling learning sebagai upaya percontohan yang diberikan oleh konselor, tenaga pendidik, dan stake holder yang mencerminkan keluhuran karakter. Sebagai contoh disiplin kedatangan di sekolah dan kedisiplinan melaksanakan ibadah. Guna memberikan rasa tanggung jawab kepada siswa, sekolah mewajibkan semua pembimbing yang ada di sekolah untuk berakhlak baik sehingga dapat ditiru oleh siswanya. Pihak sekolah membentuk koordinator pula. Koordinator yang dimaksudkan yaitu koordinator sholat tahajud, koordinator sholat dhuha, dan koordinator menyambut siswa setiap pagi sebelum masuk sekolah. Selain itu, dalam memberikan modelling, konselor dituntut berusaha untuk bisa berkesan bagi siswanya yakni melalui aktif dalam kegiatan siswa, memberikan perintah disertai partisipasi dalam perintah tersebut.

Teori modelling learning dipelopori oleh Albert Bandura. Modelling (peniruan) atau meniru sesungguhnya tidak tepat untuk mengganti kata modelling karena modelling bukan sekedar menirukan atau mengulangi apa yang dilakukan oleh model (orang lain) tetapi modelling melibatkan penambahan dan atau pengurangan tingkah laku yang teramati, menggeneralisasi berbagai pengamatan sekaligus, dan melibatkan proses kognitif. Melalui modelling orang dapat memperoleh perilaku baru. Hal ini dimungkinkan karena adanya kemampuan kognitif. Stimulus berbentuk tingkah laku model ditransformasikan menjadi gambaran mental dan yang penting lagi ditransformasikan menjadi simbol verbal yang dapat diingat kembali di masa mendatang. Jadi dapat diketahui bahwa layanan bimbingan dan konseling dengan teknik modelling merupakan bantuan yang diberikan melalui model figur dari seseorang sehingga menjadi contoh bagi orang lain. Model figur tersebut menjadi stimulus bagi orang lain sehingga dapat direspon menjadi kebiasaan yang dilakukan.

Selain mempelajari tingah laku baru, modelling mempunyai dua macam dampak terhadap tingkah laku lama. Pertama, tingkah laku model yang diterima secara sosial dapat memperkuat respon yang sudah dimiliki pengamat. Kedua, dapat melemahkan tingkah laku yang tidak diterima secara sosial (McLeod, 2010). Bandura meyakini bahwa pembelajaran dengan mengamati jauh lebih efisien dari pada pembelajaran dengan mengalami langsung. Melalui pengamatan terhadap orang lain, manusia mempelajari respons mana yang diikuti hukuman atau yang mana yang tidak mendapat penguatan. Sebagai contoh teknik modelling yaitu seorang anak yang meniru tokoh-tokoh yang ada di televisi atau iklan. Hal ini terjadi karena ada pengamatan dan ketertarikan terhadap model.

Ada dua pembelajaran melalui pengamatan (Observation Learning) yaitu yang pertama, pembelajaran melalui pengamatan dapat terjadi melalui kondisi yang dialami orang lain atau vicarious learning. Contohnya, seorang pelajar melihat temannya dipuji atau ditegur oleh gurunya kerana perbuatannya, maka ia kemudian meniru melakukan perbuatan lain yang tujuannya sama ingin dipuji oleh gurunya. Kejadian ini merupakan contoh dari penguatan melalui pujian yang dialami orang lain atau vicarious learning. Kedua, pembelajaran melalui pengamatan meniru perilaku suatu model meskipun model itu tidak mendapatkan penguatan atau pelemahan pada saat pengamat itu sedang memperhatikan model itu mendemonstrasikan sesuatu yang ingin dipelajari oleh pengamat tersebut dan mengharapkan mendapat pujian atau penguatan apabila menguasai secara tuntas apa yang dipelajari itu. Model tidak harus diperagakan oleh seseorang secara langsung, tetapi dapat juga menggunakan seseorang pemeran atau visualisasi tiruan sebagai model.

Contoh penerapan modelling dalam bimbingan dan konseling yaitu pada studi yang dilakukan oleh Krisphianti, Hidayah, \& Irtadji (2016) yang membuktikan bahwa teknik storytelling menggunakan media topeng Malang (sebagai salah satu bentuk dari simbolik model) efektif untuk meningkatkan karakter fairness siswa kelas VI sekolah dasar. Hasil studi Mandala, Dantes, \& Setuti (2013), diketahui bahwa penerapan konseling behavioral 
dengan teknik modelling dapat berfungsi secara efektif untuk meningkatkan emotional intelligence siswa. Hasil studi Mandala tersebut, diperkuat dengan hasil studi Novitasari, Hidayah, \& Mappiare-AT (2017), yang menyatakan bahwa strategi modelling partisipan dalam bantuan teman sebaya dapat meningkatkan komunikasi interpersonal siswa. Hal ini senada dengan hasil studi Sari dkk, (2015) yang menunjukkan peningkatan keterampilan komunikasi antar pribadi dengan menerapkan konseling behavioral dengan teknik modelling.

Lebih lanjut, studi Retnaningdyastuti \& Ajie (2014), menunjukkan bahwa melalui teknik modelling dalam bimbingan klasikal terbukti dapat meningkatkan kedisiplinan siswa kelas VII SMP Negeri 2 Semarang. Penggunaan teknik pemodelan (modelling) juga terbukti efektif untuk meningkatkan perencanaan karir siswa di kelas $X$ SMA Yasmida Ambarawa (Adiputra, 2015). Penerapan teknik modelling dalam layanan bimbingan dan konseling, dapat digunakan oleh konselor sebagai strategi dalam mewujudkan pendidikan karakter.

Penerapan clasical condisioning learning sebagai salah satu upaya penanaman karakter baik pada siswa. Konselor sekolah memberikan pedampingan kepada siswa. Pendampingan yang dimaksudkan dimana konselor atau guru bersama-sama dengan siswanya melakukan suatu pekerjaan. Selain memberikan contoh yang positif, sekolah juga memfasilitasi siswanya, seperti memberikan kaos kaki jika terdapat siswa yang terlambat dan tidak memakai kaos kaki sesuai jadwalnya. Selain itu konselor juga menciptakan suasana yang mendukung, hangat dalam hubungan disertai dengan sarana dan prasarana yang mendukung, seperti masjid, kantin kejujuran, perpustakaan, taman baca/gazebo sekolah dan lain-lain. Sekolah juga melakukan upaya memroses siswa yang melanggar aturan dan menindaknya dengan aturan yang berlaku.

Peraturan di sekolah telah dinformasikan sejak awal siswa masuk di sekolah tersebut, baik kepada wali siswa maupun kepada siswa itu sendiri. Peraturan tersebut meliputi ketertiban jam masuk sekolah, standarisasi motor yang diperbolehkan masuk di lingkungan sekolah, jadwal seragam, jadwal kegiatan-kegiatan, budaya sekolah yang harus dianut siswa, dan fasilitas yang dapat dipergunakan oleh siswa. Melalui pemberian informasi sedini mungkin kepada siswa ataupun wali siswa, sekolah dapat menjalin kerjasama antar ketiganya, yaitu orangtua, sekolah, dan siswa itu sendiri. Hal ini yang menjadi langkah awal dalam upaya implementasi teknik classical conditioning.

Menurut De Houwer, Barnes-Holmes, \& Moors (2013) belajar diartikan sebagai perubahan perilaku versus determinan perubahan perilaku. Pembelajaran mengacu pada perubahan perilaku yang disebabkan oleh pengalaman sehingga dapat dikatakan bahwa pembelajaran sebagai efek pengalaman pada perilaku. Conditioning adalah suatu bentuk belajar yang memungkinkan organisme memberikan respon terhadap suatu rangsang yang sebelumnya tidak menimbulkan respon itu, atau suatu proses untuk mengintroduksi berbagai reflek menjadi sebuah tingkah laku. Jadi classical conditioning sebagai pembentuk tingkah laku melalui proses persyaratan (conditioning process). Follette \& Dalto (2015) menyatakan pengkondisian klasik biasanya didefinisikan sebagai proses dimana stimulus netral sebelumnya datang untuk memberikan kontrol atas respons melalui perpasangan stimulus netral dengan stimulus yang secara alami (yaitu, tanpa pelatihan sebelumnya) menimbulkan respons. Penguatan pembelajaran sangat mempengaruhi model pengkondisian, memberikan penjelasan kuat tentang perilaku yang diperoleh, dan pengamatan fisiologis yang mendasarinya (Lesaint dkk, 2014).

Menurut Kryukov (2012), ada tiga paradigma dasar pengkondisian klasik yaitu keterlambatan, jejak, dan pengkondisian konteks di mana penyajian stimulus terkondisi atau konteks biasanya memprediksi stimulus tanpa syarat. Hal terpenting dalam belajar menurut teori conditioning ialah adanya latihan-latihan yang berkelanjutan. Hal utama dalam teori ini ialah belajar yang terjadi secara otomatis. Segala tingkah laku manusia tidak lain adalah hasil daripada latihan-latihan atau kebiasaan-kebiasaan mereaksi terhadap syarat-syarat tertentu yang dialaminya dalam kehidupannya.

Jozefowiez (2014) menjelaskan tiga arti yang berbeda dalam classical conditioning yaitu prosedur, fenomena pembelajaran yang diamati dalam prosedur yang sama, dan proses pembelajaran yang menjelaskan fenomena tersebut yang diamati dalam prosedur itu. Jika melihat makna ketiga hal tersebut dari sudut pandang evolusioner, nampaknya sangat tidak mungkin satu proses pengkon- 
disian Pavlovian bertanggung jawab untuk belajar dalam semua prosedur yang diklasifikasikan sebagai pengkondisian Pavlov. Oleh karena itu, ketiga hal tersebut saling berkaitan dan berhubungan.

Penerapan kolaborasi dari ke tiga teknik tersebut dalam upaya konselor menanamkan pendidikan karakter yang berimplikasi pada kehidupan sehari-hari di MA Matholi'ul Anwar Karanggeneng Lamongan dinilai efektif. Hal ini ditunjukkan dengan minimnya pelanggaran tata tertib yang dilakukan siswa dan tertanamnya perilaku siswa yang baik, mulai dengan terterapkannya 6S (salam, salim, senyum, sapa, sopa dan santun), kedisiplinan siswa, ketertiban berkendara, taat dalam peribadatan, tanggung jawab akan kebersihan lingkungan dan kejujuran siswa dalam ujian.

Suyanto (2009) mendefinisikan karakter sebagai cara berpikir dan berperilaku yang menjadi ciri khas tiap individu untuk hidup dan bekerja sama, baik dalam lingkup keluarga, masyarakat, bangsa, maupun negara. Individu yang berkarakter baik adalah individu yang bisa membuat keputusan dan siap mempertanggungjawabkan setiap akibat dari keputusan yang dibuat. Menurut Ellen (dalam Amri dkk, 2011), pendidikan karakter adalah usaha paling penting yang pernah diberikan kepada manusia. Pembangunan karakter merupakan tujuan luar biasa dari sistem pendidikan yang benar. Orang tua dan guru harus sadar bahwa pembangunan tabiat yang agung adalah tugas utama. Remaja yang memiliki karakter dan kecerdasan emosi akan lebih tehindar dari masalah kenakalan remaja seperti tawuran, narkoba, miras, dan perilaku seks bebas. Pendidikan karakter mampu mendidik siswa menjadi pribadi yang unggul dalam aspek pengetahuan, cerdas secara emosional, dan kuat dalam keperibadian.

Zubaedi (2011) menjelaskan bahwa pendidikan karakter di Indonesia didasarkan pada sembilan pilar karakter dasar. Karakter dasar menjadi tujuan pendidikan karakter. Kesembilan pilar karakter dasar ini, antara lain: 1) cinta kepada Allah dan semesta beserta isinya; 2) tanggung jawab, disiplin, dan mandiri; 3) jujur; 4) hormat dan santun; 5) kasih sayang, pedili, dan kerja sama; 6) percaya diri, kreatif, kerja keras, dan pantang menyerah; 7) keadilan dan kepemimpinan; 8) baik dan rendah hati, dan 9) toleransi, cinta damai, dan persatuan. Konselor sekolah mempunyai tanggung jawab untuk membantu siswa dalam mengembangkan kesembilan karakter dasar tersebut.

Sebagai salah satu pihak yang berkepentingan dengan pendidikan karakter maka konselor sekolah harus berkomitmen untuk melaksanakan pendidikan karakter karena bimbingan dan konseling juga merupakan bagian dari sistem pendidikan yang mampu membantu siswa dalam mengembangkan potensi dan kepribadiannya (Permana, 2015). Hal ini senada dengan pendapat Sukitman \& Mulyadi (2014) yang menyatakan bahwa salah satu solusi menyelesaikan permasalahan dalam hal pendidikan karakter, perlu dilakukan suatu upaya dalam layanan bimbingan dan konseling. Tujuan studi yang dilakukan Sukitman \& Mulyadi (2014) untuk mengembangkan sekaligus menjawab tantangan dan masalah pendidikan melalui integrasi pendidikan karakter terhadap layanan bimbingan konseling. Strategi layanan pendidikan karakter dalam bimbingan dan konseling dapat melalui layanan dasar, layanan responsif, perencanaan individu, dan dukungan sistem. Keberhasilan dalam menyelenggarakan dan menanamkan nilai-nilai kehidupan melalui pendidikan karakter dapat pula dipengaruhi oleh cara atau pendekatan yang dipergunakan dalam menyampaikan. Terkait dengan kegiatan pendidikan karakter di sekolah, konselor sekolah wajib memfasilitasi pengembangan dan penumbuhan karakter serta tanpa mengabaikan penguasaan hard skills lebih lanjut yang diperlukan dalam perjalanan hidup serta dalam mempersiapkan karier. Oleh karena itu, penerapan kolaborasi teknik insight, modelling dan classical conditioning merupakan salah satu upaya yang dilakukan konselor sekolah sebagai wujud partisipasinya dalam pengembangan dan penumbuhan karakter pada siswa. Hal itu senada dengan pendapat Wangid (2010) bahwa konselor sekolah hendaknya berpartisipasi aktif dalam pengembangan dan penumbuhan karakter pada siswa..

\section{SIMPULAN}

Berdasarkan hasil studi maka dapat disimpulkan bahwa penerapan kolaborasi teknik insight, modelling, dan classical conditioning dalam implementasi pendidikan karakter siswa dinilai efektif. Hal ini dikarenakan dari ketiga teknik 
tersebut mempunyai kaitan yang sangat erat sebagai penunjang diterapkannya pendidikan karakter bagi siswa. Siswa akan secara sadar mengimplementasikan hasil dari pendidikan karakter jika siswa mempunyai pemahaman yang baik akan pentingnya berkarakter baik. Hal ini akan diperkuat oleh contoh-contoh yang di berikan oleh orangorang terdekatnya yang dapat dilihat dengan jelas sehingga siswa akan tertarik dan mengikuti contoh-contoh yang diberikan. Guna mencapai hasil yang maksimal dan menyeluruh maka pengkondisian lingkungan akan memberikan dampak pembiasaan siswa untuk mengimplementasikan karakter-karakter baik yang diharapkan sekolah. Penerapan kolaborasi teknik ini memerlukan dukungan dan kerjasama dari semua warga sekolah karena faktor dasar keberhasilan penerapan teknik ini yaitu kekompakan visi misi semua warga sekolah dan konsistensi pendidik. Hasil studi sebagai upaya baru untuk mengembangkan karakter baik pada siswa melalui kolaborasi teknik insight, modelling, dan classical conditioning sehingga memiliki peranan dalam pendidikan karakter yang berimplikasi dalam kehidupan sehari-hari siswa.

\section{REFERENSI}

Abror, Abd Rachman. (2002). Psikologi Pendidikan. Yogyakarta: PT. Tiara Wacana Yogya.

Adiputra, S. (2015). Penggunaan Teknik Modelling Terhadap Perencanaan Karir Siswa. Fokus Konseling: Jurnal Bimbingan dan Konseling, 1 (1), 45-56.

Amri, Sofan, dkk. (2011). Impelemntasi Pendidikan Karakter dalam Pembelajaran. Jakarta: Prestasi Pustaka.

Danek, A. H., Wiley, J., \& Öllinger, M. (2016). Solving Classical Insight Problems Without Aha! Experience: 9 dot, 8 coin, and Matchstick Arithmetic Problems. The Journal of Problem Solving, 9 (1), 4.

De Houwer, J., Barnes-Holmes, D., \& Moors, A. (2013). What is learning? On the nature and merits of a functional definition of learning. Psychonomic Bulletin $\mathcal{E}$ Review, 20 (4), 631-642.

Follette, W. C., \& Dalto, G. (2015). Classical Conditioning Methods in Psychotherapy. International Encyclopedia of the Social $\mathbb{E}$ Behavioral Sciences, 2nd edition, 3, 764-770.

Hidayati, Wiji \& Purnami, Sri. (2008). Psikologi
Perkembangan. Yogyakarta: Teras.

Jozefowiez, J. (2014). The Many Faces of Pavlovian Conditioning. International Journal of Comparative Psychology, 27 (4), 526-536.

Kryukov, V. I. (2012). Towards a Unified Model of Pavlovian Conditioning: Short Review of Trace Conditioning Models. Cognitive Neurodynamics, 6 (5), 377-398.

Kusmanto, A. S. (2015). Kontribusi Konselor dalam Membentuk Karakter Peserta Didik SMA. Jurnal Konseling Gusjigang, 1 (1).

Lesaint, F., Sigaud, O., Flagel, S. B., Robinson, T. E., \& Khamassi, M. (2014). Modelling Individual Differences In The Form Of Pavlovian Conditioned Approach Responses: A Dual Learning Systems Approach With Factored Representations. PLoS com putational biology, 10 (2), e1003466.

Krisphianti, Y.D., Hidayah, Nur., \& Irtadji, Moh. (2016). Efektivitas Teknik Storytelling Menggunakan Media Wayang Topeng Malang untuk Meningkatkan Karakter Fairness Siswa. PSIKOPEDAGOGIA Jurnal Bimbingan dan Konseling, 5 (1), 17-23.

Mandala, S. J., Dantes, N. D., \& Setuti, N. M. (2013). Penerapan Konseling Behavioral dengan Teknik Modelling untuk Meningkatkan Emotional Intelligence Siswa Pada Kelas X AP1 SMK Negeri 1 Seririt Kabupaten Bulelengpenerapan Konseling Behavioral dengan Teknik Modelling untuk Meningkatkan Emotional Intelligence. Jurnal Ilmiah Bimbingan Konseling, 1 (1).

McLeod, John. (2010). Pengantar Konseling Teori dan Studi Kasus. (Ed. 1, Cet. 3). Jakarta: Kencana Predan Media Group.

Novitasari, Z., Hidayah, N., \& Mappiare-AT, A. (2017). Keefektifan Strategi Modelling Partisipan Dalam Bantuan Teman Sebaya (Peer Helping) Untuk Meningkatkan Komunikasi Interpersonal Siswa SMA. Jurnal Pendidikan: Teori, Penelitian, dan Pengembangan, 2 (3), 363-370.

Permana, Eko Jati. (2015). Pelaksanaan Layanan Bimbingan dan Konseling di Madrasah Aliyah Negeri 2 Banjarnegara. PSIKOPEDAGOGIA Jurnal Bimbingan dan Konseling, 4 (2), 143-151.

Prayitno dan Belferik Manulang. (2011). Pendidikan Karakter dalam Pembangunan Bangsa. Jakarta: 
Grasindo.

Retnaningdyastuti, M. T. S., \& Ajie, R. (2014). Penggunaan Teknik Modeling Dalam Bimbingan Klasikal Untuk Meningkatkan Kedisiplinan Siswa. EmpatiJurnal Bimbingan dan Konseling, 1 (1), 37-52.

Rogers, C. R. (1944). The Development of Insight in a Counseling Relationship. Journal of Consulting Psychology, 8 (6), 331.

Sari, N. L. G. M. M., Sedanayasa, G., Antari, N. N. M., \& Erg, M. (2015). Penerapan Konseling Behavioral dengan Teknik Modelling untuk Meningkatkan Keterampilan Komunikasi Antar Pribadi Pada Siswa Kelas X 6 SMA Negeri 1 Sawan. Jurnal Ilmiah Bimbingan Konseling, 3 (1).

Sukitman, T., \& Mulyadi, M. (2014). Pendidikan Karakter dan Bimbingan Konseling (Antisipasi Kekeraasan dan Pelecehan Seksual Pada Tingkat Sekolah di Kab. Sumenep). Jurnal Pelopor Pendidikan, 5 (1), 17-30.

Suyanto. (2009). Urgensi Pendidikan Karakter. (Online), (http://www. mandikdasmen.depdiknas.go.id/ web/pages/urgensi.html), diakses 12 Maret 2017.

Undang-Undang Republik Indonesia No. 20

Tahun 2003 tentang Sistem Pendidikan Nasional. (2003). Jakarta: Erlangga

Uno, Hamzah B. (2006). Orientasi Baru dalam Psikologi Pembelajaran. Jakarta: PT. Bumi Aksara.

Vess, Kimberly A. \& Halbur, Duane A. (2003). Character Education: What Counselor Educators Need To Know. (Online), (https://www.ericdigests.org/ 2003-5/character.htm), diakses 12 Maret 2017.

Wangid, M. N. (2010). Peran Konselor Sekolah dalam Pendidikan Karakter. Jurnal Cakrawala Pendidikan, 1(3), 173-186.

Zubaedi. (2011). Desain Pendidikan Karakter: Konsepsi dan Aplikasinya dalam Lembaga Pendidikan. Jakarta: Kencana Prenada Media Group. 